\title{
Fluorescence Sensing Properties of 2-(2'-Hydroxyphenyl)quinoline and Derivatives
}

\author{
Aasif Helal, Sang Hoon Lee, Wen Xiu Ren, Chan Sik Cho, and Hong-Seok Kim* \\ Department of Applied Chemistry, Kyungpook National University, Daegu 702-701, Korea. *E-mail: kimhs@knu.ac.kr \\ Received March 11, 2011, Accepted March 24, 2011
}

\begin{abstract}
Novel chemosensors based on 2-(2'-hydroxyphenyl)quinoline were prepared and evaluated for sensing metal cations. The photophysical properties of chemosensors 1-3 were examined and their ion-selectivity was evaluated by measuring their fluorescent emission responses to alkali, alkaline earth, and transition metal ions. Chemosensors 1, 2 and $\mathbf{3}$ show ratiometric and enhanced fluorescence changes with transitional metals that are efficient fluorescence quenchers, especially 3 has a high binding constant with $\mathrm{Hg}^{2+}$ in $\mathrm{CH}_{3} \mathrm{CN}$.
\end{abstract}

Key Words : Fluorescence, Chemosensor, Quinoline, Phenol, $\mathrm{Hg}^{+2}$

\section{Introduction}

The use of chelating ligands bearing quinoline nitrogen as a coordinating atom represents an important target when the coordination of transitional metals is taken into consideration, it combines two complementary and important features. The marked coordinating capability of the nitrogen coupled with the chromophoric characteristics of the quinoline ring induces the formation of stable metal complexes with potential photophysical properties. ${ }^{1}$ Substituted quinolines and isoquinolines are known to have interesting photochemical and photophysical properties. These compounds are commonly used as fluorescent probes, standards, and fluorogenic substrates for enzymatic assays and anion recognition. $^{2}$ Among these, 8-hydroxyquinoline (Fig. 1) is one of the most important chelators for metal ions, and has found significant applications in a variety of investigations involving metal complexes. ${ }^{3}$ An important property that makes it even more attractive as a chelator is the appreciable change in its fluorescence with metal binding. ${ }^{4}$ Therefore, it has been used extensively to construct highly sensitive fluorescent chemosensors for the sensing and imaging of metal ions and their chelates, of important biological and or environmental significance, ${ }^{5-8}$ in particular those which are major components for organic light-emitting diodes (OLEDs). ${ }^{9}$

It is known that the excited-state intramolecular proton transfer (ESIPT) from the 8-hydroxy to the quinolino $\mathrm{N}$ atom, makes 8-hydroxyquinoline weakly fluorescent and metal binding blocks the ESIPT channel, thereby restoring its fluorescence.,7a Thus 8-hydroxyquinoline could be employed to build fluorescent chemosensors for metal ions via ESIPT suppression and increased fluorescence signal on metal binding. ${ }^{4 a}$ Recently we have reported on a few hydroxyphenyl-thiazole and aminophenyl-thiazole based chemosensors where the thiazole ring is incorporated with a pyridine, phenyl, or another thiazole phenol moiety at position 4 for their use as a ratiometric fluorescence sensor of zinc, ${ }^{10 \mathrm{a}, 10 \mathrm{~b}}$ anions, ${ }^{10 \mathrm{c}, 10 \mathrm{~d}}$ or the dual chemosensing of zinc and copper, ${ }^{10 \mathrm{e}}$ respectively. Based on these two observations we designed chemosensors 1, 2, and 3. Moreover to enhance the metal binding ability, the introduction of additional binding sites at the C-2 and or C-7 positions adjacent to the original binding sites in 8-hydroxyquinoline has been extensively examined. ${ }^{5-8}$ In this respect we chose compound 2 which was synthesized previously ${ }^{11}$ and prepared derivatives $\mathbf{1}$ and $\mathbf{3}$ to examine the photophysical and binding characteristics with different metal cations. In this respect these compounds can be viewed as an extension of more common hydroxyquinolines or 10-hydroxybenzo $[h]$ quinoline.

\section{Experimental Section}

The general experimental procedures for melting points ${ }^{1} \mathrm{H}$ and ${ }^{13} \mathrm{C} \mathrm{NMR}$, UV-vis, and the fluorescence spectra have been described previously. ${ }^{10 \mathrm{~d}}$ All of the measurements were operated at $298 \mathrm{~K}$. Analytical grade acetonitrile was purchased from Merck, and dried over $\mathrm{CaH}_{2}$ before use. Compound $\mathbf{2}$ was prepared by the procedure given in the literature. ${ }^{11}$ All other materials for synthesis were purchased from Aldrich Chemical Co. and used without further purification. The solutions of metal ions were prepared from their perchlorate salts of analytical grade, and then subsequently diluted to prepare working solutions.

Synthesis of 1. A $1.0 \mathrm{M}$ solution of $\mathrm{BBr}_{3}(1.6 \mathrm{~mL}, 1.66$ $\mathrm{mmol})$ in dry $\mathrm{CH}_{2} \mathrm{Cl}_{2}(5 \mathrm{~mL})$ was slowly added to a solution of $2(100 \mathrm{mg}, 0.43 \mathrm{mmol})$ in dry $\mathrm{CH}_{2} \mathrm{Cl}_{2}(15 \mathrm{~mL})$ at $-78{ }^{\circ} \mathrm{C}$ for $1 \mathrm{~h}$. The cold bath was removed and the mixture was stirred at room temperature for $5 \mathrm{~h}$, poured into water and stirred for $1 \mathrm{~h}$. The reaction mixture was extracted with $\mathrm{CH}_{2} \mathrm{Cl}_{2}$. The organic layer was washed, dried over anhydrous $\mathrm{Na}_{2} \mathrm{SO}_{4}$, and evaporated. The residue was purified using $\mathrm{SiO}_{2}$ column chromatography (elution with $5 \%$ EtOAc in hexane) to give 1 in $83 \%$ yield. $\mathrm{mp} 110-111{ }^{\circ} \mathrm{C}\left(\mathrm{CH}_{2} \mathrm{Cl}_{2}\right.$ hexane); ${ }^{1} \mathrm{H} \mathrm{NMR}\left(400 \mathrm{MHz}, \mathrm{CDCl}_{3}\right) \delta 6.75(\mathrm{t}, J=8.0 \mathrm{~Hz}$, $1 \mathrm{H}), 6.92(\mathrm{~d}, J=8.0 \mathrm{~Hz}, 1 \mathrm{H}), 7.16(\mathrm{t}, J=7.0 \mathrm{~Hz}, 1 \mathrm{H}), 7.31$ $(\mathrm{t}, J=8.0 \mathrm{~Hz}, 1 \mathrm{H}), 7.50(\mathrm{t}, J=8.0 \mathrm{~Hz}, 1 \mathrm{H}), 7.56(\mathrm{~d}, J=8.0$ $\mathrm{Hz}, 1 \mathrm{H}), 7.69$ (d, $J=8.0 \mathrm{~Hz}, 1 \mathrm{H}), 7.77$ (m, 2H), 7.99 (d, $J=$ $8.0 \mathrm{~Hz}, 1 \mathrm{H}) ;{ }^{13} \mathrm{C} \mathrm{NMR}\left(100 \mathrm{MHz}, \mathrm{CDCl}_{3}\right) \delta 117.4,118.7$, $118.9,126.6,126.8,126.9,127.1,127.4,127.6,130.7,132.2$, 137.9, 144.5, 157.8, 161.0; Anal. Calcd for: $\mathrm{C}_{15} \mathrm{H}_{11} \mathrm{NO}$ : $\mathrm{C}$, 
81.43; H, 5.01; N, 6.33; Found C, 81.07; H, 5.43; N, 6.07.

Synthesis of 3. Benzoyl chloride ( $80 \mathrm{mg}, 0.54 \mathrm{mmol}$ ) was added slowly to a solution of $1(60 \mathrm{mg}, 0.27 \mathrm{mmol})$ in pyridine $(10 \mathrm{~mL})$ and stirred at room temperature overnight. The reaction mixture was then neutralized with a $2 \mathrm{~N} \mathrm{NaOH}$ solution and extracted with $\mathrm{CH}_{2} \mathrm{Cl}_{2}$. The organic layer was washed with water, dried and evaporated. The residue was purified using $\mathrm{SiO}_{2}$ column chromatography $(5 \% \mathrm{EtOAc}$ in hexane) to give 3 in $90 \%$ yield. mp $79-80{ }^{\circ} \mathrm{C}\left(\mathrm{CH}_{2} \mathrm{Cl}_{2}-\right.$ hexane); ${ }^{1} \mathrm{H}$ NMR (400 MHz, $\left.\mathrm{CDCl}_{3}\right) \delta$ 7.38-7.41 (m, 2H), $7.43(\mathrm{~s}, 1 \mathrm{H}), 7.45-7.49(\mathrm{~m}, 2 \mathrm{H}), 7.54-7.57(\mathrm{~m}, 2 \mathrm{H}), 7.62(\mathrm{dt}$, $J=1.5,7.7 \mathrm{~Hz}, 1 \mathrm{H}), 7.70(\mathrm{~d}, J=8.6 \mathrm{~Hz}, 1 \mathrm{H}), 7.73(\mathrm{~d}, J=$ $8.4 \mathrm{~Hz}, 1 \mathrm{H}), 7.93(\mathrm{dd}, J=1.8,7.6 \mathrm{~Hz}, 1 \mathrm{H}), 7.98(\mathrm{~d}, J=8.6$ $\mathrm{Hz}, 1 \mathrm{H}), 8.07(\mathrm{~s}, 1 \mathrm{H}), 8.11(\mathrm{dd}, J=1.5,8.6 \mathrm{~Hz}, 2 \mathrm{H}) ;{ }^{13} \mathrm{C}$ NMR (100 MHz, $\left.\mathrm{CDCl}_{3}\right) \delta 121.7,123.7,126.6,126.7,126.9$, $127.0,127.5,128.6,129.6,129.7,130.2,130.3,131.4$, 133.3, 133.5, 136.4, 147.9, 148.7, 155.8, 165.3; Anal. Calcd for $\mathrm{C}_{23} \mathrm{H}_{16} \mathrm{NO}_{2}$ : C, 81.21; H, 4.65; N, 4.30. Found: C, 81.30; $\mathrm{H}, 4.69 ; \mathrm{N}, 4.21$.

\section{Results and Discussion}

The requisite compound $\mathbf{2}$ was prepared according to the reported procedure. ${ }^{11}$ Deprotection of the methoxy group in $\mathbf{2}$ with $\mathrm{BBr}_{3}$ provides $\mathbf{1}$ in good yield, while the benzoate $\mathbf{3}$ was obtained via a simple one-step reaction of $\mathbf{1}$ with benzoyl chloride as shown in Scheme 1. The ${ }^{1} \mathrm{H}$ NMR, ${ }^{13} \mathrm{C}$ NMR and elemental analysis confirmed the structures of $\mathbf{1}$, 2, and 3 (Fig. 1).

The absorption studies of $\mathbf{1}, \mathbf{2}$, and $\mathbf{3}$ with various cations were carried out in acetonitrile at a concentration of $60 \mu \mathrm{M}$ (Fig. 2). The absorption spectrum of sensor $\mathbf{1}$ shows a red shift of $25 \mathrm{~nm}$ and $23 \mathrm{~nm}$ and an increase in the molar absorbance as compared to $\mathbf{2}$ and $\mathbf{3}$, respectively. This can be attributed to a $\pi-\pi^{*}$ transition; this is favoured by the planar orientation enforced by the intramolecular hydrogen bond-
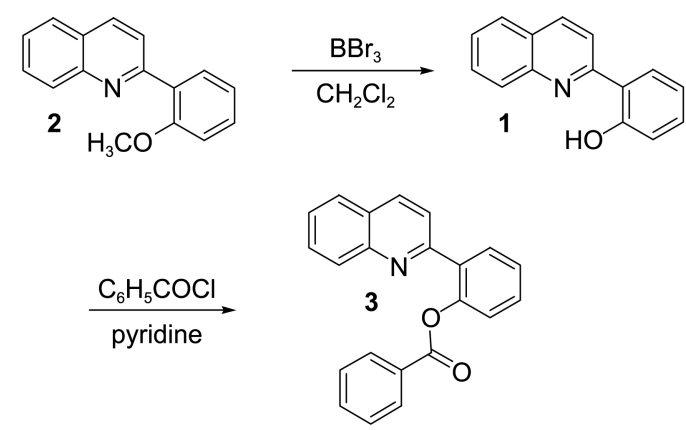

Scheme 1

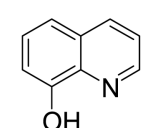

8-hydroxyquinoline

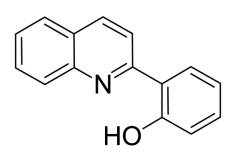

1

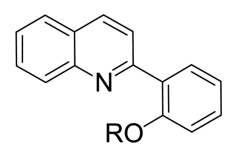

2: $\mathrm{R}=\mathrm{CH}_{3}$ 3: $\mathrm{R}=\mathrm{COC}_{6} \mathrm{H}_{5}$
Figure 1. Structures of 8-hydroxyquinoline, 2(2'-hydroxyphenyl)quinoline and their derivatives.

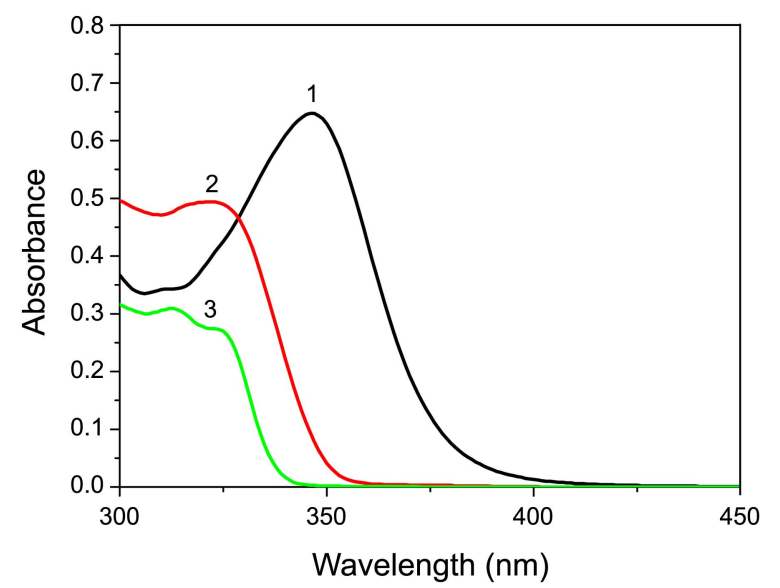

Figure 2. UV-vis spectra of 1, 2, and $\mathbf{3}(60 \mu \mathrm{M})$ in $\mathrm{CH}_{3} \mathrm{CN}$.

Table 1. UV-vis data of $\mathbf{1}, \mathbf{2}, \mathbf{3}$, and their metal complexes

\begin{tabular}{lcccccc}
\hline & \multicolumn{3}{c}{$\mathbf{1}$} & \multicolumn{2}{c}{$\mathbf{2}$} & \multicolumn{2}{c}{$\mathbf{3}$} \\
\cline { 2 - 7 } & $\lambda_{\max }(\mathrm{nm})$ & $\log \varepsilon$ & $\lambda_{\max }(\mathrm{nm})$ & $\log \varepsilon$ & $\lambda_{\max }(\mathrm{nm})$ & $\log \varepsilon$ \\
\hline $\mathrm{None}$ & 346 & 4.03 & 322 & 3.91 & 313 & 3.72 \\
$\mathrm{Na}^{+}$ & 346 & 4.03 & 322 & 3.92 & 313 & 3.71 \\
$\mathrm{Cs}^{+}$ & 346 & 4.02 & 322 & 3.91 & 312 & 3.70 \\
$\mathrm{Rb}^{+}$ & 346 & 4.02 & 322 & 3.91 & 312 & 3.70 \\
$\mathrm{Mg}^{2+}$ & 346 & 4.03 & 323 & 3.92 & 313 & 3.71 \\
$\mathrm{Ca}^{2+}$ & 346 & 4.03 & 332 & 3.92 & 312 & 3.69 \\
$\mathrm{Cu}^{2+}$ & 357 & 4.07 & 328 & 4.00 & 326 & 3.86 \\
& 448 & 3.53 & 363 & 4.11 & & \\
$\mathrm{Ni}^{2+}$ & 346 & 4.03 & 323 & 3.91 & 312 & 3.71 \\
$\mathrm{Co}^{2+}$ & 346 & 4.03 & 323 & 3.91 & 313 & 3.70 \\
$\mathrm{Zn}^{2+}$ & 346 & 4.03 & 326 & 3.96 & 314 & 3.72 \\
& & & 362 & 3.89 & 324 & 3.72 \\
$\mathrm{Fe}^{2+}$ & 358 & 4.09 & 325 & 3.96 & 330 & 4.05 \\
& & & 363 & 3.86 & & \\
$\mathrm{Ag}^{+}$ & 346 & 4.03 & 322 & 3.91 & 312 & 3.70 \\
$\mathrm{Hg}^{2+}$ & 349 & 4.03 & 333 & 3.91 & 328 & 4.10 \\
$\mathrm{~Pb}^{2+}$ & 347 & 4.03 & 333 & 4.00 & 327 & 3.91 \\
& & & 363 & 4.15 & & \\
\hline
\end{tabular}

ing between the quinoline nitrogen and phenolic hydrogen. ${ }^{10 \mathrm{c}, 12}$ Among the tested cations, sensor 1 produces red shifts with an enhanced molar extinction coefficient (Table 1) only upon binding with transitional metal cations $\mathrm{Cu}^{2+}$ ( $357 \mathrm{~nm}$, and $448 \mathrm{~nm}$ ) and $\mathrm{Fe}^{2+}(358 \mathrm{~nm})$. Chemosensors 2 and 3 produce red shifts and the enhancement of molar absorbance with transitional heavy metal cations such as $\mathrm{Hg}^{2+}, \mathrm{Pb}^{2+}, \mathrm{Cu}^{2+}$ and $\mathrm{Fe}^{2+}$. This is due to the stabilization effect produced by the metal chelation enhanced charge transfer from the substituted phenyl ring to the quinoline nitrogen (Fig. 3).

Spectrofluorimetric analysis was carried out by adding 10 equiv of different metal cations to $60 \mu \mathrm{M}$ solutions of $\mathbf{1 , 2}$, and $\mathbf{3}$ in acetonitrile (Fig. 5). In the case of $\mathbf{2}$ there is an emission peak at $379 \mathrm{~nm}$ which is produced by the charge transfer from the methoxy group of the phenyl ring to the 


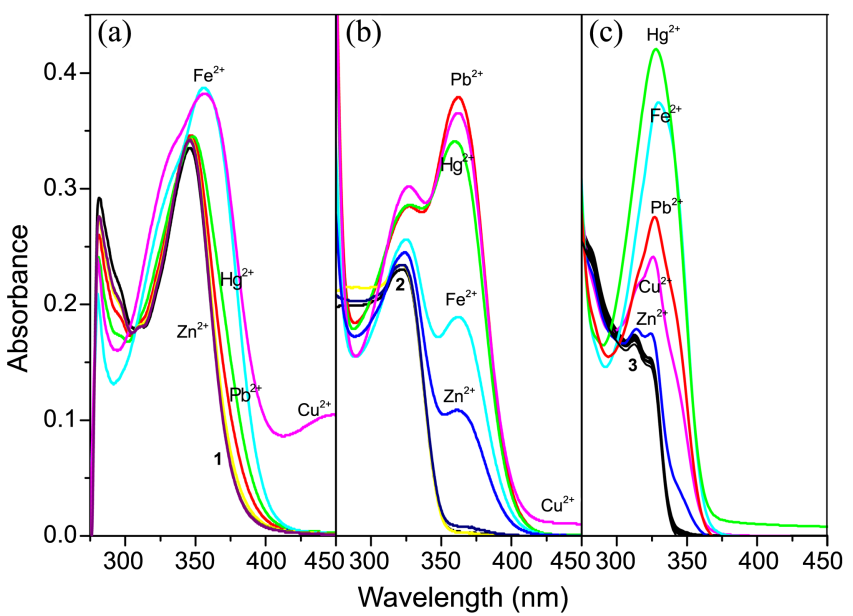

Figure 3. Changes in UV-vis spectra of (a) 1, (b) 2, and (c) 3 (60 $\mu \mathrm{M})$ upon the addition of various metal ions (10 equiv) in $\mathrm{CH}_{3} \mathrm{CN}$.

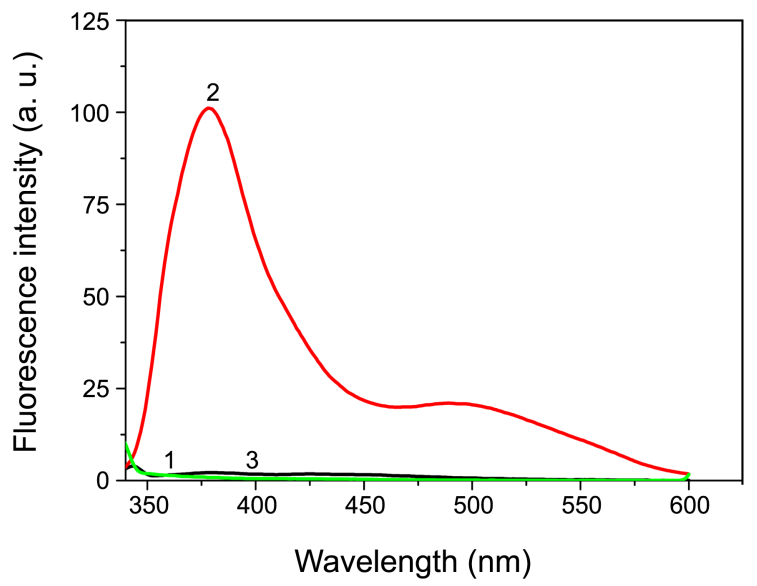

Figure 4. Fluorescence emission spectra of 1, 2, and $\mathbf{3}(60 \mu \mathrm{M})$ in $\mathrm{CH}_{3} \mathrm{CN}\left(\lambda_{\mathrm{ex}}=340 \mathrm{~nm}\right.$ for $\mathbf{1}, \lambda_{\mathrm{ex}}=314 \mathrm{~nm}$ for $\mathbf{2}, \lambda_{\mathrm{ex}}=302 \mathrm{~nm}$ for $\left.\mathbf{3}\right)$.

Table 2. Fluorescence data of 1, 2, 3, and their metal complex

\begin{tabular}{lcccccc}
\hline & \multicolumn{3}{c}{$\mathbf{1}$} & \multicolumn{2}{c}{$\mathbf{2}$} \\
\cline { 2 - 7 } & $\lambda(\mathrm{nm})$ & $\mathrm{I} / \mathrm{I}_{\mathrm{o}}$ & $\lambda(\mathrm{nm})$ & $\mathrm{I} / \mathrm{I}_{\mathrm{o}}$ & $\lambda(\mathrm{nm})$ & $\mathrm{I} / \mathrm{I}_{\mathrm{o}}$ \\
\hline $\mathrm{Host}$ & 378 & 1.00 & 379 & 1.00 & 338 & 1.00 \\
$\mathrm{Na}^{+}$ & 378 & 1.01 & 383 & 1.07 & 337 & 1.00 \\
$\mathrm{Cs}^{+}$ & 378 & 1.05 & 379 & 1.06 & & \\
$\mathrm{Rb}^{+}$ & 378 & 1.05 & 381 & 1.05 & & \\
$\mathrm{Mg}^{2+}$ & 378 & 0.90 & 375 & 1.69 & 338 & 1.02 \\
$\mathrm{Ca}^{2+}$ & 378 & 0.44 & 381 & 0.92 & & \\
$\mathrm{Cu}^{2+}$ & 501 & 7.13 & 508 & 13.26 & 455 & 9.64 \\
$\mathrm{Ni}^{2+}$ & 378 & 1.00 & 383 & 1.11 & 338 & 0.98 \\
$\mathrm{Co}^{2+}$ & 378 & 0.92 & 377 & 1.25 & 338 & 0.98 \\
$\mathrm{Zn}^{2+}$ & 501 & 4.77 & 385 & 1.21 & 456 & 2.24 \\
$\mathrm{Fe}^{2+}$ & 501 & 4.40 & 508 & 16.23 & 454 & 5.64 \\
$\mathrm{Ag}^{+}$ & 378 & 1.09 & 378 & 1.06 & & \\
$\mathrm{Hg}^{2+}$ & 501 & 7.45 & 508 & 9.92 & 456 & 12.66 \\
$\mathrm{~Pb}^{2+}$ & 501 & 8.33 & 508 & 4.53 & 455 & 8.23 \\
\hline
\end{tabular}

quinolino $\mathrm{N}$ atom (Fig. 4, Table 2). Chelation with the transitional metal enhances the charge or electron transfer from the methoxy to the quinoline group in $\mathbf{2}$ thus making it
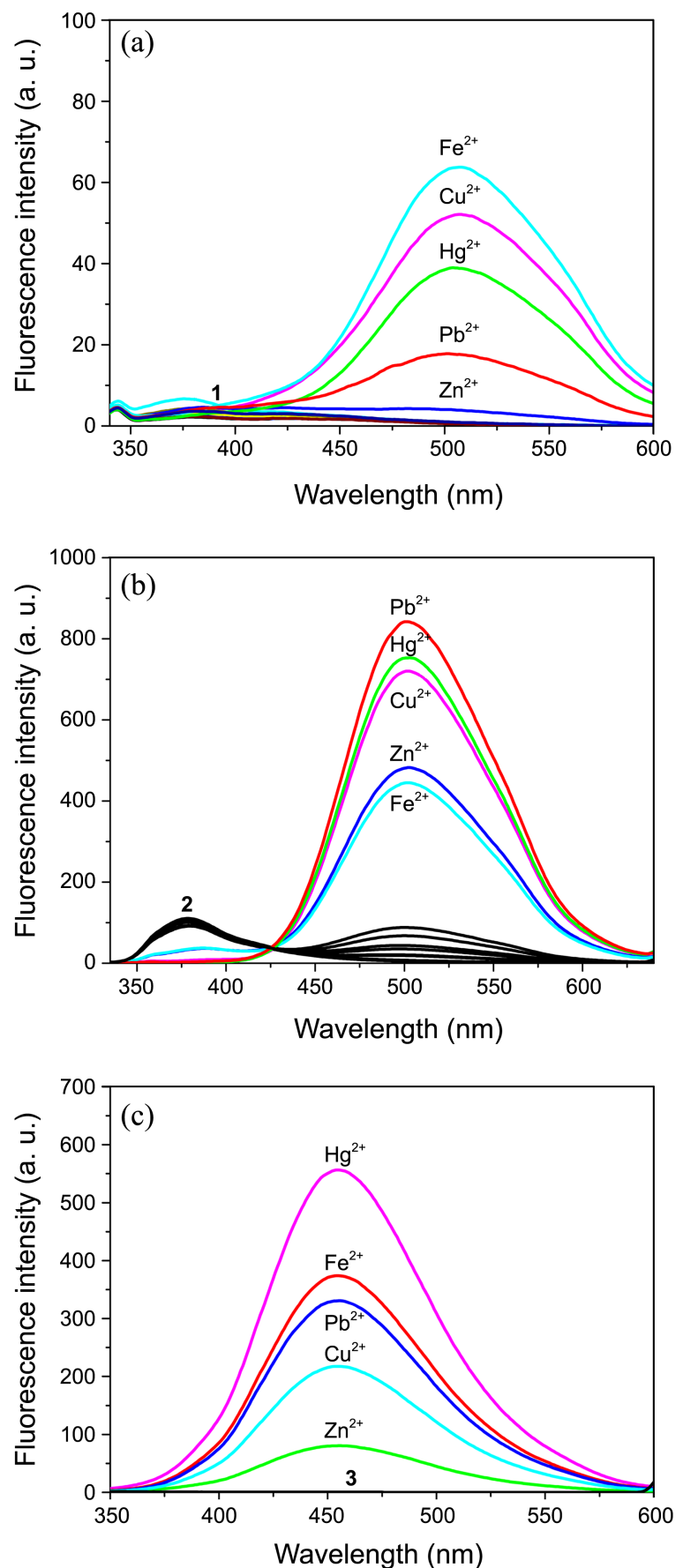

Figure 5. Changes in fluorescence spectra of (a) 1, (b) 2, and (c) 3 $(60 \mu \mathrm{M})$ upon the addition of various metal ions (10 equiv) in $\mathrm{CH}_{3} \mathrm{CN}\left(\lambda_{\mathrm{ex}}=340 \mathrm{~nm}\right.$ for $\mathbf{1}, \lambda_{\mathrm{ex}}=314 \mathrm{~nm}$ for $\mathbf{2}, \lambda_{\mathrm{ex}}=302 \mathrm{~nm}$ for $\left.\mathbf{3}\right)$.

more stable and causing a large red shift to $508 \mathrm{~nm} \mathrm{Hg}^{2+}$ and $\mathrm{Cu}^{2+}$ produce a large ratiometric change from $379 \mathrm{~nm}$ to 508 $\mathrm{nm}$ instead of quenching (Fig. 5(b), Table 2). Deprotection of the methoxy group of $\mathbf{2}$ produces a free hydroxyl group in chemosensor 1 that causes ESIPT between the $\mathrm{O}-\mathrm{H}$ and the quinolino nitrogen resulting in the disappearance of fluorescence (Fig. 4). Binding with the transitional metals block the ESIPT channel, thereby restore the fluorescence however at $501 \mathrm{~nm}$, the intensity is very low (Figure 5(a), Table 2). ${ }^{4,13}$

In both of these cases we can see that $\mathrm{Hg}^{2+}$ and $\mathrm{Cu}^{2+}$ which 


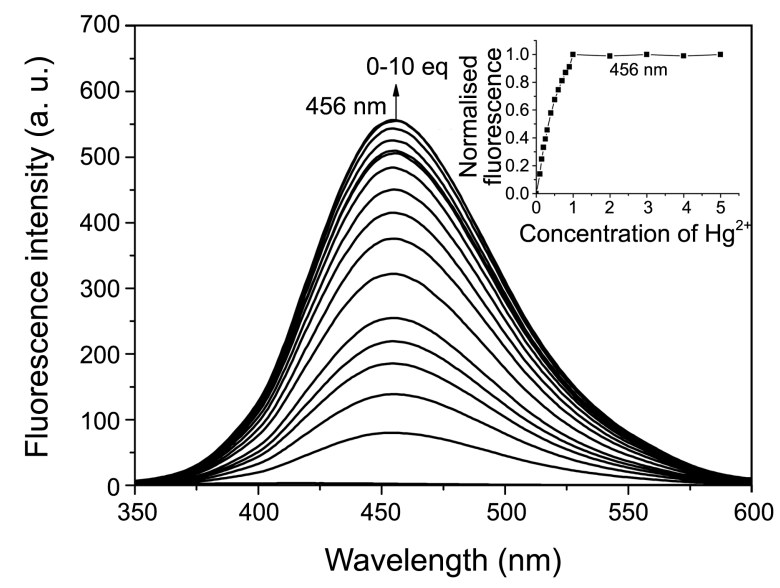

Figure 6. Changes in fluorescence spectra of $3(60 \mu \mathrm{M})$ upon the addition of $\mathrm{Hg}\left(\mathrm{ClO}_{4}\right)_{2}$ in $\mathrm{CH}_{3} \mathrm{CN}$. Inset: mol ratio plot of emissions at $456 \mathrm{~nm}\left(\lambda_{\mathrm{ex}}=302 \mathrm{~nm}\right)$.

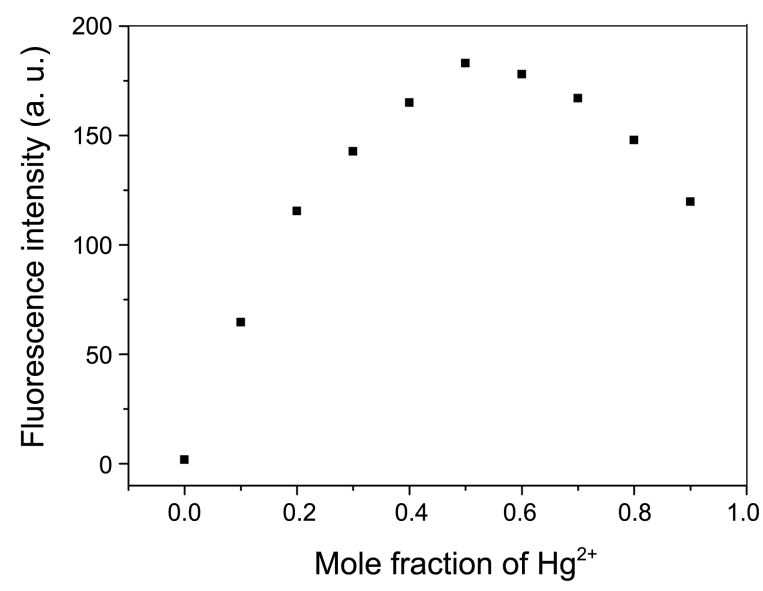

Figure 7. Job's plot of 3 with $\mathrm{Hg}\left(\mathrm{ClO}_{4}\right)_{2}$ in $\mathrm{CH}_{3} \mathrm{CN}$.

are highly efficient fluorescence quenchers undergo a large ratiometric and enhanced fluorescence change in $\mathbf{2}$ and $\mathbf{1}$ respectively. In order to produce a ratiometric change, enhance metal binding, and enhance the fluorescence intensity by introducing the additional binding sites, we prepared the benzoate derivative 3 . It was designed on the basis of the consideration that, in the esters, the carbonyl oxygen lone pair is brought into proximity of the quinoline fluorophore, making them weakly fluorescent due to the radiationless process via the $\mathrm{n}-\pi^{*}$ state. ${ }^{14}$ Binding with the transitional metal cations enhanced fluorescence emissions due to the blocking of the radiationless channel. The competitive experiment shows that $\mathrm{Hg}^{2+}$ produces the largest enhancement followed by $\mathrm{Fe}^{2+}, \mathrm{Pb}^{2+}, \mathrm{Cu}^{2+}$, and $\mathrm{Zn}^{2+}$ (Fig. 5(c) and Table 2). This shows that the binding of $\mathrm{Hg}^{2+}$ blocks the radiationless decay and the emission of $\mathrm{Hg}^{2+}-\mathbf{3}$ originates from the $\pi-\pi^{*}$.

The fluorescence titration of $\mathbf{3}$ with $\mathrm{Hg}^{2+}$ shows an enhanced emission peak at $456 \mathrm{~nm}$ (Fig. 6) and the Job's plot with $\mathrm{Hg}^{2+}$ shows a 1:1 binding ratio (Fig. 7). The binding constants calculated from the fluorescent titration experiments were found to be maximum for $\mathrm{Hg}^{2+}$ and were followed by $\mathrm{Cu}^{2+}>\mathrm{Pb}^{2+}>\mathrm{Zn}^{2}>\mathrm{Fe}^{2+}$ (Table 3$){ }^{15}$
Table 3. Binding constants $\left(K_{a}, \mathrm{M}^{-1}\right)$ of $\mathbf{2}$ and $\mathbf{3}$ based on fluorescence emission spectra

\begin{tabular}{cccccc}
\hline Sensor & $\mathrm{Hg}^{2+}$ & $\mathrm{Pb}^{2+}$ & $\mathrm{Zn}^{2+}$ & $\mathrm{Cu}^{2+}$ & $\mathrm{Fe}^{2+}$ \\
\hline $\mathbf{2}$ & $1.50 \times 10^{3}$ & $4.96 \times 10^{2}$ & $\mathrm{ND}$ & $6.12 \times 10^{2}$ & $\mathrm{ND}$ \\
$\mathbf{3}$ & $9.34 \times 10^{3}$ & $9.05 \times 10^{3}$ & $3.53 \times 10^{3}$ & $9.06 \times 10^{3}$ & $5.75 \times 10^{2}$ \\
\hline ND: Not detectable
\end{tabular}

In summary, we have developed chemosensor 2-(2'-hydroxyphenyl)-quinoline (1) and two of its derivatives $\mathbf{2}$ and $\mathbf{3}$. Their photophysical properties show that $\mathbf{2}$ and $\mathbf{3}$ produce ratiometric and enhanced emissions on binding with transitional metals; especially $\mathrm{Hg}^{2+}$ and $\mathrm{Cu}^{2+}$ which are highly efficient fluorescence quenchers. In chemosensor $\mathbf{2}$, suitable charge transfer to the quinolino nitrogen on metal binding results in the red shifted and enhanced fluorescence in all transitional metals. In 1, the blocking of the ESIPT on metal binding causes the enhancement of fluorescence but it was insignificant as compared to $\mathbf{2}$ and $\mathbf{3}$. Chemosensor $\mathbf{3}$ shows a stronger binding with the $\mathrm{Hg}^{2+}$ ion and an enhancement in fluorescence due to the blocking of the radiationless $n-\pi^{*}$ channel.

Acknowledgments. This research was supported by the NRF grant funded by MEST in Korea (NRF 2010-0010070). The Research Institute of Industrial Technology at Kyungpook National University also supported A.H.

\section{References and Notes}

1. (a) Fahrni, C. J.; O'Halloran, T. V. J. Am. Chem. Soc. 1999, 121, 11448. (b) Thompson, R. B. Curr. Opin. Chem. Biol. 2005, 9, 526. (c) Chien, T. C.; Dias, L. G.; Arantes, G. M.; Santos, L. G. C.; Triboni, E. R.; Bastos, E. L.; Politi, M. J. J. Photochem. Photobiol. A 2008, 194, 37. (d) Quang, D. T.; Kim, J. S. Chem. Rev. 2010, 110, 6280. (e) Zhang, J. F.; Kim, J. S. Anal. Sci. 2009, $25,1271$.

2. (a) Katzenellenbogen, J. A.; Haroutounian, S. A. Photochem. Photobiol. 1988, 47, 503. (b) Swinburne, A. N.; Paterson, M. J.; Beeby, A.; Steed, J. W. Org. Biomol. Chem. 2010, 8, 1010. (c) Goswami, S.; Chakrabarty, R. Tetrahedron Lett. 2009, 50, 5994. (d) Zhang, D. Inorg. Chem. Commun. 2009, 12, 1255.

3. (a) Zhang, L.; Meggers, E. J. Am. Chem. Soc. 2005, 127, 74. (b) Jiang, P.; Guo, Z. Coord. Chem. Rev. 2004, 248, 205. (c) Zelder, F. Z.; Brunner, J.; Kramer, R. Chem. Commun. 2004, 902. (d) Valeur, B.; Leray, I. Coord. Chem. Rev. 2000, 205, 3. (e) Song, K. C.; Kim, J. S.; Park, S. M.; Chung, K.-C.; Ahn, S.; Chang, S.-K. Org. Lett. 2006, 8, 3413. (f) Li, N.; Xu, Q.; Xia, X.; Wang, L.; Lu, J.; Wen, X. Mater. Chem. Phys. 2009, 114, 339.

4. (a) Bardez, E.; Devol, I.; Larrey, B.; Valeur, B. J. Phys. Chem. B 1997, 101, 7786. (b) Han, D. Y.; Kim, J. M.; Kim, J.; Jung, H. S.; Lee, Y. H.; Zhang, J. F.; Kim, J. S. Tetrahedron Lett. 2010, 51, 1947. (c) Canovese, L.; Visentin, F.; Chessa, G.; Levi, C.; Nikolov, P. Inorg. Chim. Acta 2009, 362, 3925.

5. (a) Shults, M. D.; Imperiali, B. J. Am. Chem. Soc. 2003, 125, 14248. (b) Shults, M. D.; Pearce, D. A.; Imperiali, B. J. Am. Chem. Soc. 2003, 125, 10591. (c) Pearce, D. A.; Jotterand, N.; Carrico, I. S.; Imperiali, B. J. Am. Chem. Soc. 2001, 123, 5160. (d) Jotterand, N.; Pearce, D. A.; Imperiali, B. J. Org. Chem. 2001, 66, 3224. (e) Walkup, G. K.; Imperiali, B. J. Org. Chem. 1998, 63, 6727.

6. (a) Bronson, R. T.; Montalti, M.; Prodi, L.; Zaccheroni, N.; Lamb, 
R. D.; Dalley, N. K.; Izatt, R. M.; Bradshaw, J. S.; Savage, P. B. Tetrahedron 2004, 60, 11139. (b) Bronson, R. T.; Bradshaw, J. S.; Savage, P. B.; Fuangswasdi, S.; Lee, S. C.; Krakowiak, K. E.; Izatt, R. M. J. Org. Chem. 2001, 66, 4752. (c) Prodi, L.; Montalti, M.; Zaccheroni, N.; Bradshaw, J. S.; Izatt, R. M.; Savage, P. B. Tetrahedron Lett. 2001, 42, 2941. (d) Prodi, L.; Bargossi, C.; Montalti, M.; Zaccheroni, N.; Su, N.; Bradshaw, J. S.; Izatt, R. M.; Savage, P. B. J. Am. Chem. Soc. 2000, 122, 6769. (e) Su, N.; Bradshaw, J. S.; Zhang, X. X.; Song, H.; Savage, P. B.; Xue, G.; Krakowiak, K. E.; Izatt, R. M. J. Org. Chem. 1999, 64, 8855.

7. (a) Winkler, J. K.; Bowen, C. M.; Michelet, V. J. Am. Chem. Soc. 1998, 120, 3237. (b) Hayashi, M.; Ishii, M.; Hiratani, K.; Saigo, K. Tetrahedron Lett. 1998, 39, 6215. (c) Baret, P.; Beguin, C. G.; Boukhalfa, H.; Caris, C.; Laulhere, J.-P.; Pierre, J.-L.; Serratrice, G. J. Am. Chem. Soc. 1995, 117, 9760 .

8. (a) Moon, S. Y.; Cha, N. R.; Kim, Y. H.; Chang, S.-K. J. Org. Chem. 2004, 69, 181. (b) Kim, Y.-H.; Youk, J. S.; Moon, S. Y.; Choe, J.-I.; Chang, S.-K. Chem. Lett. 2004, 33, 702.

9. (a) Ghosh, P.; Bharadwaj, P. K.; Roy, J.; Ghosh, S. J. Am. Chem. Soc. 1997, 119, 11903. (b) Ramachandram, B.; Samanta, A. Chem. Commun. 1997, 1037. (c) Nolan, E. M.; Lippard, S. J. J. Am. Chem. Soc. 2003, 125, 14270. (d) Guo, X.; Qian, X.; Jia, L. J. Am. Chem. Soc. 2004, 126, 2272. (e) Davis, M. J.; Kragor, C. H.;
Reddie, K. G.; Wilson, H. C.; Zhu, Y.; Dore, T. M. J. Org. Chem. 2009, 74, 1721 .

10. (a) Helal, A.; Kim, H.-S. Tetrahedron Lett. 2009, 50, 5510. (b) Helal, A.; Kim, S.-H.; Kim, H.-S. Tetrahedron 2010, 66, 9925. (c) Helal, A.; Thao, N. T. T.; Lee, S.; Kim, H.-S.; J. Inclusion Phenom. Macrocyclic Chem. 2010, 66, 87. (d) Helal, A.; Kim, H.-S. Tetrahedron 2010, 66, 7097. (e) Helal, A.; Lee, S. H.; Kim, S. H.; Kim, H.-S. Tetrahedron Lett. 2010, 51, 3531.

11. Cho, C. S.; Kim, B. T.; Kim, T. J.; Shim, S. C. Chem. Commun. 2001, 2576.

12. Keck, J.; Kramer, H. E. A.; Port, H.; Hirsch, T.; Fischer, P.; Rytz, G. J. Phys. Chem. 1996, 100, 14468.

13. Launay, F.; Alain, V.; Destandau, E. A.; Ramos, N.; Bardez, E. A.; Baret, P.; Pierre, J.-L. New J. Chem. 2001, 25, 1269.

14. (a) Zhou, Z.; Fahrni, C. J. J. Am. Chem. Soc. 2004, 126, 8862. (b) Leray, I.; O'Reilly, F.; Habib Jiwan, J.-L.; Soumillion, J.-Ph.; Valeur, B. Chem. Commun. 1999, 795. (c) Young, V. G.; Quiring, H. L.; Sykes, A. K. J. Am. Chem. Soc. 1997, 119, 12477.

15. (a) Connors, K. A. Binding Constants: the Measurement of Molecular Complex Stability; Wiley: New York, 1987; pp 21-101; 339-343. (b) Forgues, S. F.; LeBris, M. T.; Gutte, J. P.; Valuer, B. J. Phys. Chem. 1988, 92, 6233. (c) Gnuplot 4 (www.gnuplot.info). 